\title{
Coffee and Caffeine Intake among Students of the Brazilian Northeast
}

\author{
Andreza Gomes Penafort 1 , Isabella Barbosa Pereira Carneiro², \\ Antônio Augusto Ferreira Carioca², Maria Olganê Dantas Sabry², \\ Francisco José Maia Pinto², Helena Alves de Carvalho Sampaio ${ }^{2 *}$ \\ ${ }^{1}$ University of Fortaleza, Fortaleza, Brazil \\ ${ }^{2}$ State University of Ceara, Fortaleza, Brazil \\ Email: "dr.hard2@gmail.com
}

Received 25 November 2015; accepted 22 January 2016; published 25 January 2016

Copyright @ 2016 by authors and Scientific Research Publishing Inc.

This work is licensed under the Creative Commons Attribution International License (CC BY). http://creativecommons.org/licenses/by/4.0/

c) (7) Open Access

\section{Abstract}

The purpose of this study was to evaluate the pattern of intake of coffee and caffeine-containing food among students in a post-secondary institution in northeastern Brazil. We interviewed 498 students. Among these students, $72.3 \%(n=360)$ reported to consume coffee, with a higher prevalence among women (68.3\%) and students aged between 18 and 25 years $(82.8 \%)$. The student's residence itself was the top location for taking coffee $(90.6 \%)$ and the most widely used method of preparation was brewing coffee using a cloth filter (82.5\%). The average intake of coffee was $199.0 \pm 230.6 \mathrm{ml} / \mathrm{day}$, with a frequency of $1.6 \pm 1.4$ times a day and concentration between $4 \%-12 \%$. Coffee was the main source of caffeine and the average daily intake of $147.3 \pm 141.2 \mathrm{mg}$ of caffeine was low. The data showed that the intake of coffee and caffeine does not represent a risk factor for the population studied. On the other hand, the scarcity of national studies on the subject points to the need of similar research about customer profile and pattern of consumption of coffee and caffeine, especially regarding the preparation technique of coffee, featuring benefits or risks for the development of chronic diseases.

\section{Keywords}

Coffee, Caffeine, Chronic Disease

\section{Introduction}

Coffee represents one of the main agricultural products in Brazil, with a total production of 48.09 million bags

\footnotetext{
${ }^{*}$ Corresponding author.
}

How to cite this paper: Penafort, A.G., Carneiro, I.B.P., Carioca, A.A.F., Sabry, M.O.D., Pinto, F.J.M. and de Carvalho Sampaio, H.A. (2016) Coffee and Caffeine Intake among Students of the Brazilian Northeast. Food and Nutrition Sciences, 7, 3036. http://dx.doi.org/10.4236/fns.2016.71004 
of coffee in 2010, as estimated by the National Supply Company [1]. Caffeine, a substance first described in Germany in 1820 by the chemist Ferdinan Runge, is the most investigated substance in coffee [2]. Undoubtedly coffee serves as a primary source of caffeine for an adult individual, being consumed at different levels and segments of the Brazilian population [3].

Caffeine is commonly found in drinks such as coffee, tea and soda; in cocoa or chocolate containing products, or in medications [4]-[6]. Caffeine exerts its pharmacological effects primarily by acting as a competitive antagonist of adenosine-receptor in the cerebral cortex, peripheral blood, kidneys, heart, gastrointestinal and respiratory tracts [3]. The adenosine neurotransmitter usually acts as an inhibitor and depressive factor in the brain. By antagonizing these effects, caffeine stimulates the release of norepinephrine and the spontaneous activation of noradrenergic neurons. The stimulant autonomic action of caffeine results in mental and cardiac stimulation, release of catecholamines. Another effect of caffeine is the sympathetic stimulation, leading to a modest increase in blood pressure and lipolysis, with an increase in free-fatty acid levels similar to what is observed in stress situation, when the body reserves are mobilized.

The caffeine content of coffee varies according to its preparation (filtration, percolation, boiling, instant, espresso), which can differ in various parts of the world and as a result, the caffeine content in a cup of coffee varies considerably [7]. In Brazil, the most commonly used methods are the coffee filtered in the paper filter, the Brazilian (filtered using cloth filter), boiled coffee (unfiltered) and instant coffee [5].

Coffee contains a lipid portion, composed mainly of triacylglycerol, sterols and tocopherols, the typical components found in all common vegetable oils [8]. In the past few years, the scientific community has focused their efforts in investigating the possible effects of coffee on human health.

Epidemiological and experimental studies have investigated the relationship between coffee and caffeine intake and chronic diseases such as cardiovascular disease, type 2 diabetes mellitus, cancer, Parkinson disease, as well as other metabolic, reproductive and inflammatory conditions [9]-[18]. There is evidence from the literature of positive effects of coffee and caffeine intake in chronic disease prevention [4] [16] [19]. However, the question whether the excessive coffee and/or caffeine intake has adverse health effects remains inconclusive.

A literature review by Ruxton [6], including studies published between 1992 and 2007, assessed the amount of caffeine that could lead to a maximum benefit and lower risk to health with respect to mood, cognitive function, hydration, urine output and performance, finding that such an amount could reach up to $400 \mathrm{mg} /$ day.

There are very few studies investigating the intake habits of coffee consumers, especially in Brazil, making it difficult to assess whether coffee consumption by a population group represents a risk or a benefit to health. Therefore, the objective of this study was to evaluate the pattern of consumption of coffee and caffeinecontaining foods among students of a post-secondary institution in northeastern Brazil.

\section{Methods}

This study was part of a research program evaluating the pattern of coffee and caffeine-containing food intake among students at a post-secondary institution in Fortaleza-Ceara, Brazil. The research program aimed to assess the association between coffee intake and chronic diseases and was approved by the Ethics Board in the institution.

The study population was composed of students enrolled in undergraduate courses located on the main campus of the institution. The sample was determined after conducting a pilot study to identify the prevalence of coffee consumption, the main source of caffeine in the diet. Thus, considering the prevalence found of $65 \%$ and an alpha error of $4 \%, 498$ students were included. Pregnancy was an exclusion criterion due to possible interference in the pattern of consumption of coffee and caffeine-containing foods.

The portion sizes for the coffee powder were obtained by direct weighing, using a digital scale (Nutri Plenna ${ }^{\circledR}$ ) with $2 \mathrm{~kg}$ capacity and sensitivity of $1 \mathrm{~g}$. The intake of other foods containing caffeine was transformed into grams by constant standardization [20] and information obtained from product labels. The total daily caffeine intake was calculated by summing the caffeine contained in each food consumed, obtained by specific amount of caffeine in food multiplied by the proportional weight and frequency of consumption of each product. Specific tables were used to obtain the amount of caffeine in each food [21]-[23].

As there is still controversy in the literature about the safety of caffeine consumption, a moderate intake below $300 \mathrm{mg} /$ day was adopted as the upper limit of safe intake that would not entail risk to a person's health [4] [19]. All data was analysed using SPSS (Statistical Program of Social Science), version 15.0. Descriptive statis- 
tics as well as chi-square test were performed, adopting a significance level of 5\%.

\section{Results}

Table 1 provides a description of the students. Coffee intake was reported by $72.3 \%(n=360)$ of the students. The habit of drinking coffee was more prevalent among women $68.3 \%(n=246)$, with a significant difference between both sexes $(\mathrm{p}=0.020)$. The age group between 18 and 25 years $(82.8 \%)$ was the one with a greatest prevalence of individuals reporting to drink coffee regularly $(\mathrm{p}=0.021)$. The student's residence was the place where coffee was consumed more frequently $(90.6 \%)$, followed by workplace $(40.0 \%)$ and at their relatives house (15.0\%).

The most commonly reported method to prepare coffee was by using a cloth filter (83\%), followed by soluble coffee (33\%) and paper filter (25\%). The cloth filter was mainly used at home (48.1\%) (Table 2).

The average frequency of coffee consumption was $1.5 \pm 1.1$ times/day. Coffee intake at home range from one to fifteen times/day, with an average frequency of $1.6 \pm 1.3$ times/day. The average frequency of coffee consumption at other locations was $1.3 \pm 1.0$ times/day.

Table 1. Characteristics and coffee intake of all individuals.

\begin{tabular}{lll}
\hline Variable & N & \% \\
\hline Sex & & 68.3 \\
Female & 246 & 31.7 \\
Male & 114 & 82.8 \\
Age (years) & 298 & 12.2 \\
18 - 25 & 44 & 3.6 \\
$26-32$ & 13 & 1.4 \\
$33-40$ & 5 & - \\
$41-48$ & - & - \\
$49-56$ & - & 33.9 \\
$>56$ & & 17.8 \\
Location where coffee was consumed & 326 & 90.6 \\
Home & 122 & \\
University & 64 & \\
Other & & \\
\hline
\end{tabular}

Table 2. Method of coffee preparation $(n=360)$.

\begin{tabular}{|c|c|c|c|c|c|c|}
\hline & \multicolumn{2}{|c|}{ Home } & \multicolumn{2}{|c|}{ Other location } & \multicolumn{2}{|c|}{ Total } \\
\hline & $\mathbf{N}$ & $\%$ & $\mathbf{N}$ & $\%$ & $\mathbf{N}$ & $\%$ \\
\hline Cloth filter & 173 & 48.1 & 124 & 34.4 & 297 & 82.5 \\
\hline Soluble coffee & 109 & 30.3 & 10 & 2.8 & 119 & 33.1 \\
\hline Paper filter & 66 & 18.3 & 25 & 6.9 & 91 & 25.3 \\
\hline Percolated & 17 & 4.7 & 1 & 0.3 & 18 & 5.0 \\
\hline Expresso & - & - & 17 & 4.7 & 17 & 4.7 \\
\hline Decaffeinated & 7 & 1.9 & - & - & 7 & 1.9 \\
\hline Not reported & - & - & 15 & 4.2 & 15 & 4.2 \\
\hline
\end{tabular}


The concentration of brewed coffee varied between 4 and $12 \%$, with an average of $0.09 \pm 0.54 \mathrm{~g} / \mathrm{ml}$ and 0.05 $\pm 0.16 \mathrm{~g} / \mathrm{ml}$ for the coffee consumed at home and at other locations, respectively, with no statistical difference between these concentrations $(\mathrm{p}=0.050$ ). The average daily coffee consumption was $199.0 \pm 230.6 \mathrm{~mL} /$ day. The largest amounts of coffee were consumed at home $(143.4 \pm 161.8 \mathrm{~mL}$ versus $37.8 \pm 83.6 \mathrm{~mL}$ at other locations).

Most students reported that their coffee intake was mainly in the morning (68.4\%), while $18.4 \%$ had a higher intake in the afternoon and $13.2 \%$ in the evening. Only $31.6 \%$ of coffee consumers were able to identify situations in which they were more likely to drink coffee: during breaks (49\%) and before exams (37\%).

The average overall caffeine intake reported was $147.3 \pm 141.2 \mathrm{mg} / \mathrm{day}$. As expected, coffee was the main source of caffeine intake, contributing to $158.4 \pm 133.1 \mathrm{mg} /$ day of caffeine intake. Other caffeine-containing foods reported were soda and chocolate (Table 3). Cold and pain medications (dorflex ${ }^{\circledR}$, neosaldina ${ }^{\circledR}$, benegrip ${ }^{\circledR}$ e tylenol $D^{\circledR}$ ) were also reported as potential sources of caffeine intake.

\section{Discussion}

Coffee intake was considerably prevalent in this cohort of post-secondary students, being higher than that reported by other studies in school environments such as the study by Lima et al. [18] in which a prevalence of $54.7 \%$ was reported. However, the prevalence in our study was similar to the one reported among female Nursing and Nutrition students (73.3\%) and in population-based studies (90\%) [24] [25].

A research conducted by the Brazilian Association of Coffee Industry [2] identified that the habit of drinking coffee from childhood or even when in college is the main reason for starting or increased consumption. This could partially explain the high prevalence of coffee intake in our study.

A higher prevalence of coffee consumers was reported among women, which is consistent with data from the national survey on the coffee consumer profile [2]. A household budget survey in Brazil (2008-2009) reported a coffee intake average per capita of $215.1 \mathrm{~g} /$ day (222.3 g/day for men and $208.3 \mathrm{~g} /$ day for women) with a prevalence of consumption of $79.0 \%$ (78.7\% men and 79.3\% women). Another interesting result was the higher prevalence (83.5\%) and consumption per capita (230.3 g) in the northeast region compared to other regions of the country [26].

The habit of consuming coffee was more prevalent among individuals aged with 25 years or less. This finding conflicts with the trend shown by a research conducted in several Brazilian regions, which showed a greater prevalence among individuals aged 36 years or older [2]. Camargo et al. [27] observed a progressive increase in coffee consumption to the age group from 30 to 39 years with a decline in older individuals. This was a population-based research, involving various age groups, including older people, which may explain the discrepancies with the present findings. Nevertheless, to our knowledge there are no other studies assessing coffee consumption pattern just among young people.

Our findings were consistent with the study of Assis et al. [28], which reported that coffee is preferably consumed at home in the north-east of Brazil, as well as in rural areas. The same findings were reported by a house-

Table 3. Main sources of caffeine and daily intake (mg/day).

\begin{tabular}{ccc}
\hline Sorce of caffeine & Mean & Standard deviation \\
Coffee & 158.4 & 133.1 \\
Soda (coke) & 24.7 & 30.7 \\
Chocolate & 22.5 & 37.1 \\
Green tea & 19.8 & 27.1 \\
Black tea & 17.4 & 23.9 \\
Other types of soda & 16.3 & 26.1 \\
Medicine & 5.5 & 10.1 \\
Cocoa powder & 1.9 \\
Other & 10.2 \\
\hline
\end{tabular}


hold budget survey in Brazil (2008-2009) in which only 10\% of the population reported consuming coffee in locations other their home [26]. The same was reported by Lima [10]; for that author, drinking coffee represents a moment of gathering the family together for Brazilians, which could explain why it is mainly consumed at home.

The use of a cloth filter was the most commonly reported preparation in our study (82.5\%). Other studies, in the United States [11] and in Brazil [27] have reported filtered coffee to be most commonly consumed by their participants; however, the type of filter used was not described in these studies (paper, permanent, and cloth filters). Although the use of cloth filter is poorly discussed in the literature, this method is not recommended. The cloth filter is not capable to retain substances present in the lipid fractions of coffee: cafestol and kahweol. These two substances identified as diterpenes may exert adverse health effects, increasing cholesterol levels [29] [30], although not all studies confirm this association [18].

According to Brazilian Association of Coffee Industry [2] the cloth filter is a commonly used method to prepare coffee among Brazilians. This method is probably restricted to a few populations, hence the lack of international studies investigating the risks or even benefits associated with it.

The daily frequency of coffee consumption reported in this study was relatively lower than that in other studies. In a study using data from the Iowa Women's Health Study the frequency of coffee consumption was around 2.7 cups/day [31]. A research conducted by the Brazilian Association of Coffee Industry [2] reported that $76 \%$ of the people that drink coffee regularly have a daily intake and 18\% drink coffee at least 5 times a week. The average frequency of intake was around 24 times a month, with an average daily consumption of $222 \mathrm{ml}$, similar to what was found in the present study.

The concentration of the coffee consumed has been poorly investigated. Camargo and Toledo [27], state in their methods that the most common concentration is around $8 \%$ ( $20 \mathrm{~g}$ of coffee powder to $250 \mathrm{~mL}$ of water). Lima et al. [18] investigated the coffee intake of individuals presenting with hypertension and diabetes mellitus and reported a lower concentration of $2 \%$.

The global average daily coffee intake coincides with the findings of Camargo and Toledo [27], one of the few studies on coffee consumption in Brazil, where the average amount of daily consumption is $285 \mathrm{~mL} / \mathrm{day}$. In the study by Lima et al. [18], although individuals diagnosed with hypertension and diabetes were studied, the daily average intake was greater than in a healthy population (515.4 $\pm 405.2 \mathrm{~mL})$.

There is a gap in the literature regarding coffee consumption pattern of populations. For caffeine, the difficulty to establish a recommendation for intake by the quantity of coffee prepared lies in the fact that the amount of caffeine may vary according to many factors such as the plant of origin species, processing, concentration of the drink, preparation method and temperature [32].

For most respondents in our study there was no particular time of day for coffee consumption. However, for those who reported a time of the day they preferred to have coffee, the morning was the period reported, which seems to reflect a greater association with the traditional breakfast in the morning. Students also reported to consume coffee at night, which may coincide to the time destined to work on school assignments.

Coffee was most consumed during class intervals and before exams, which may be related to strategies consistent with the effects of caffeine as a stimulant of the central nervous system, increasing concentration and combating fatigue and somnolence [10].

Although caffeine is present in many products, coffee remains its main source followed by tea, chocolate and some types of soda [4] [32] [33]. This is partially due to the higher concentration of caffeine in coffee compared to other sources.

In addition to coffee, soda and chocolate were substantially consumed by students; however, with a smaller contribution to the total daily caffeine intake due to their lower caffeine content compared to coffee. The average of caffeine intake from chocolate-based products was similar to the one reported by Camargo et al. [27] of $16.6 \mathrm{mg} /$ day for women and $19.8 \mathrm{mg} /$ day for men. The authors reported that caffeine intake from soda was on average $18.3 \mathrm{mg}$ /day and $26.3 \mathrm{mg} /$ day for women and men, respectively. Total caffeine intake was similar to a population-based study in Brazil in which caffeine intake ranged between $126.77 \mathrm{mg} /$ day and $171.15 \mathrm{mg} / \mathrm{day}$. According to Higdon and Frei [19], such intake would not be associated with any adverse health outcomes. The authors suggest that a daily intake below $400 \mathrm{mg} /$ day is not associated with increased risk of cardiovascular disease, while $<300 \mathrm{mg} /$ day would be a safe dose regarding osteoporosis risk and $<500 \mathrm{mg} /$ day would not be associated with an increased risk of cancer.

Coffee has been associated with beneficial effects and is now considered a functional food [34]. Coffee con- 
sumption has been reported to be inversely associated with the risk of liver and kidney cancer, and to a lesser extent, breast and colorectal cancer [35]. Coffee intake has been shown to have a prebiotic effect increasing the number and metabolic activity of Bifidobacterium [36].

Another benefit from coffee intake is related to its antioxidant capacity provided by its phenolic compounds. Furthermore, these same compounds are responsible for other effects associated with coffee intake such as antimutagenic activities, anticarcinogenic properties, antibiotic, anti-inflammatory and antihypertensive [37]. Caffeine may also have positive effects if ingested in low to moderate doses, such as improvement in attention and learning ability, increased physical performance and effect on mood [37].

\section{Conclusion}

Coffee intake was highly prevalent among post-secondary students. Nevertheless, their intake is below the upper limit of $300 \mathrm{mg} /$ day for adverse effects; hence it does not represent any risk to these individuals' health. Studies further investigating the pattern of coffee, as well as the implications of different methods of the coffee preparation are needed.

\section{References}

[1] Brasil (2011) Acompanhamento da Safra Brasileira: Café. CONAB, Brasilia.

[2] ABIC (2011) Indicadores da indústria de café no Brasil. Associação Brasileira de Indústria de Café, Brasil.

[3] Mandel, H.G. (2002) Update on Caffeine Consumption, Disposition and Action. Food and Chemical Toxicology, 40, 1231-1234. http://dx.doi.org/10.1016/S0278-6915(02)00093-5

[4] Nawrot, P., Jordan, S., Eastwood, J., Rotstein, J., Hugenholtz, A. and Feeley, M. (2003) Effects of Caffeine on Human Health. Food Additives and Contaminants, 20, 1-30. http://dx.doi.org/10.1080/0265203021000007840

[5] Monteiro, M.C. and Trugo, L.C. (2005) Determination of Bioactive Compounds in Brazilian Roasted Coffees. Química Nova, 28, 637-641. http://dx.doi.org/10.1590/S0100-40422005000400016

[6] Ruxton, C.H.S. (2008) The Impact of Caffeine on Mood, Cognitive Function, Performance and Hydration: A Review of Benefits and Risks. Nutrition Bulletin, 33, 15-25. http://dx.doi.org/10.1111/j.1467-3010.2007.00665.x

[7] Lago, R.C.A. (2001) Lipídios em gräos de café. Boletim do Centro de Pesquisa e Processamento de Alimentos, 19, 319-340.

[8] Speer, K. and Kölling-Speer, I. (2006) The Lipid Fraction of the Coffee Bean. Brazilian Journal of Plant Physiology, 18, 201-216. http://dx.doi.org/10.1590/S1677-04202006000100014

[9] Villeneuve, P.J., Johnson, K.C., Hanley, A.J. and Mao, Y. (2000) Alcohol, Tobacco and Coffee Consumption and the Risk of Pancreatic Cancer: Results from the Canadian Enhanced Surveillance System Case-Control Project. Canadian Cancer Registries Epidemiology Research Group. European Journal of Cancer Prevention: The Official Journal of the European Cancer Prevention Organisation (ECP), 9, 49-58. http://dx.doi.org/10.1097/00008469-200002000-00007

[10] Lima, D.R. (2002) O Café pode ser bom para a saúde. EMBRAPA, Brasilia, 374.

[11] van Dam, R.M., Willett, W.C., Manson, J.E. and Hu, F.B. (2006) Coffee, Caffeine, and Risk of Type 2 Diabetes: A Prospective Cohort Study in Younger and Middle-Aged U.S. Women. Diabetes Care, 29, 398-403. http://dx.doi.org/10.2337/diacare.29.02.06.dc05-1512

[12] Ascherio, A., Weisskopf, M.G., O’Reilly, E.J., McCullough, M.L., Calle, E.E., Rodriguez, C. and Thun, M.J. (2004) Coffee Consumption, Gender, and Parkinson's Disease Mortality in the Cancer Prevention Study II Cohort: The Modifying Effects of Estrogen. American Journal of Epidemiology, 160, 977-984. http://dx.doi.org/10.1093/aje/kwh312

[13] Salazar-Martinez, E., Willett, W.C., Ascherio, A., Manson, J.E., Leitzmann, M.F., Stampfer, M.J. and Hu, F.B. (2004) Coffee Consumption and Risk for Type 2 Diabetes Mellitus. Annals of Internal Medicine, 140, 1-8. http://dx.doi.org/10.7326/0003-4819-140-1-200401060-00005

[14] Sudano, I., Binggeli, C., Spieker, L., Luscher, T.F., Ruschitzka, F., Noll, G. and Corti, R. (2005) Cardiovascular Effects of Coffee: Is It a Risk Factor? Progress in Cardiovascular Nursing, 20, 65-69. http://dx.doi.org/10.1111/j.0889-7204.2005.02477.x

[15] Evans, A.H., Lawrence, A.D., Potts, J., MacGregor, L., Katzenschlager, R., Shaw, K., Zijlmans, J. and Lees, A.J. (2006) Relationship between Impulsive Sensation Seeking Traits, Smoking, Alcohol and Caffeine Intake, and Parkinson’s Disease. Journal of Neurology, Neurosurgery, and Psychiatry, 77, 317-321. http://dx.doi.org/10.1136/jnnp.2005.065417

[16] Sartorelli, D.S., Fagherazzi, G., Balkau, B., Touillaud, M.S., Boutron-Ruault, M.C., de Lauzon-Guillain, B. and Clavel- 
Chapelon, F. (2010) Differential Effects of Coffee on the Risk of Type 2 Diabetes According to Meal Consumption in a French Cohort of Women: The E3N/EPIC Cohort Study. American Journal of Clinical Nutrition, 91, 1002-1012. http://dx.doi.org/10.3945/ajcn.2009.28741

[17] Kempf, K., Herder, C., Erlund, I., Kolb, H., Martin, S., Carstensen, M., Koenig, W., Sundvall, J., Bidel, S., Kuha, S. and Tuomilehto, J. (2010) Effects of Coffee Consumption on Subclinical Inflammation and Other Risk Factors for Type 2 Diabetes: A Clinical Trial. American Journal of Clinical Nutrition, 91, 950-957. http://dx.doi.org/10.3945/ajcn.2009.28548

[18] Lima, F.A.D., Vasconcelos, S.M.L., Sant’ana, A.E.G., Ataíde, T.D.R., Omena, C.M.B.D., Menezes, M.E.D.S. and Cabral Júnior, C.R. (2011) Intake of Different Coffee Preparations and Its Association with the Serum Lipid Profile of Diabetics and Hypertensive Individuals. Nutrition Reviews, 24, 109-119. http://dx.doi.org/10.1590/S1415-52732011000100011

[19] Higdon, J.V. and Frei, B. (2006) Coffee and Health: A Review of Recent Human Research. Critical Reviews in Food Science and Nutrition, 46, 101-123. http://dx.doi.org/10.1080/10408390500400009

[20] Pinheiro, A.B.V., Lacerda, E.M.A., Benzecry, E.H., Gomes, M.C.S. and COsta, V.M. (2000) Tabela para avaliação do consumo alimentar em medidas caseiras. Ateneu, Sao Paulo.

[21] Pennington, J.A.T. (1998) Bowes \& Church’s Food Values of Portions Commonly Used. Lippincott, Philadelphia.

[22] USDA (2007) Agricultural Research Service. Nutrient Data Laboratory: USDA Nutrient Database for Standard Reference.

[23] Tfouni, S.A.V., Camargo, M.C.R., Vitorino, S.H.P., Menegário, T.F. and Toledo, M.C. de F. (2007) Contribuição do guaraná em pó (Paullinia cupana) como fonte de cafeína na dieta. Revista de Nutrição, 20, 63-68. http://dx.doi.org/10.1590/S1415-52732007000100007

[24] Monteiro, M.R.P., Andrade, M.L.O., Zanirati, V.F. and Silva, R.R. (2009) Eating Habits and Intake of Female Students of Nutrition and Nursing in a Brazilian Public University. Revista APS, 12, 271-277.

[25] Sichieri, R. (2002) Dietary Patterns and Their Associations with Obesity in the Brazilian City of Rio de Janeiro. Obesity Research, 10, 42-48. http://dx.doi.org/10.1038/oby.2002.6

[26] BRASIL (2011) Pesquisa de Orçamentos Familiares 2008-2009: Análise do consumo alimentar pessoal no Brasil. Instituto Brasileiro de Geografia e Estatística (IBGE), Rio de Janeiro.

[27] Camargo, M.C., Toledo, M.C. and Farah, H.G. (1999) Caffeine Daily Intake from Dietary Sources in Brazil. Food Additives and Contaminants, 16, 79-87. http://dx.doi.org/10.1080/026520399284244

[28] Assis, E.M., Rodrigues, F.C., Fujii, J.B., Badaró, A.C.L. and Pereira, P.M. (2004) Consumo de alimentos industrializados na comunidade do centro universitário do leste de Minas Gerais. Revista Online Unileste, 2, 15.

[29] Urgert, R., Schulz, A.G. and Katan, M.B. (1995) Effects of Cafestol and Kahweol from Coffee Grounds on Serum Lipids and Serum Liver Enzymes in Humans. American Journal of Clinical Nutrition, 61, 149-154.

[30] Cavalcante, J.W., Santos Jr., P.R., Menezes, M.G., Marques, H.O., Cavalcante, L.P. and Pacheco, W.S. (2000) Influence of Caffeine on Blood Pressure and Platelet Aggregation. Arquivos Brasileiros de Cardiologia, 75, 97-105. http://dx.doi.org/10.1590/S0066-782X2000000800002

[31] Andersen, L.F., Jacobs Jr., D.R., Carlsen, M.H. and Blomhoff, R. (2006) Consumption of Coffee Is Associated with Reduced Risk of Death Attributed to Inflammatory and Cardiovascular Diseases in the Iowa Women's Health Study. American Journal of Clinical Nutrition, 83, 1039-1046.

[32] Desbrow, B., Hughes, R., Leveritt, M. and Scheelings, P. (2007) An Examination of Consumer Exposure to Caffeine from Retail Coffee Outlets. Food and Chemical Toxicology, 45, 1588-1592. http://dx.doi.org/10.1016/j.fct.2007.02.020

[33] Barone, J.J. and Roberts, H.R. (1996) Caffeine Consumption. Food and Chemical Toxicology, 34, 119-129. http://dx.doi.org/10.1016/0278-6915(95)00093-3

[34] Esquivel, P. and Jiménez, V.M. (2012) Functional Properties of Coffee and Coffee By-Products. Food Research International, 46, 488-495. http://dx.doi.org/10.1016/j.foodres.2011.05.028

[35] Nkondjock, A. (2009) Coffee Consumption and the Risk of Cancer: An Overview. Cancer Letters, 277, 121-125. http://dx.doi.org/10.1016/j.canlet.2008.08.022

[36] Jaquet, M., Rochat, I., Moulin, J., Cavin, C. and Bibiloni, R. (2009) Impact of Coffee Consumption on the Gut Microbiota: A Human Volunteer Study. International Journal of Food Microbiology, 130, 117-121. http://dx.doi.org/10.1016/j.ijfoodmicro.2009.01.011

[37] Vicente, S.J.V. (2009) Antioxidant Characterization of Coffee (Coffea arabica, L.) and the Effects of Its Oral Feed in Rats. Universidade de São Paulo, Sao Pauli. 